\title{
Induction of apoptosis underlies the Radix Rubiae-mediated anti-proliferative action on human epidermal keratinocytes: Implications for psoriasis treatment
}

\author{
WAI-PUI TSE ${ }^{1}$, CHRISTOPHER H.K. CHENG $^{2}$, CHUN-TAO CHE $^{1}$, MING ZHAO $^{1}$ and ZHI-XIU LIN ${ }^{1}$ \\ ${ }^{1}$ School of Chinese Medicine, Faculty of Science, ${ }^{2}$ Department of Biochemistry, Faculty of Medicine, \\ The Chinese University of Hong Kong, Shatin, N.T., Hong Kong SAR, P.R China
}

Received June 18, 2007; Accepted July 24, 2007

\begin{abstract}
Psoriasis is a chronic inflammatory skin disease characterized histologically by hyperproliferation and aberrant differentiation of epidermal keratinocytes. While screening 60 psoriasis-treating Chinese herbs for their anti-proliferative properties using a cultured human HaCaT keratinocyte model, we found Radix Rubiae to be highly effective. Evidence is now provided that induction of apoptosis is the underlying mechanism for the observed anti-proliferative action of Radix Rubiae. Analysis of cell cycle with PI staining showed that Radix Rubiae induced the appearance of a sub-G1 peak and cell arrest at the G1 phase. Radix Rubiae was also capable of inducing morphological changes as evidenced by nuclear condensation. DNA fragmentation was clearly demonstrated by gel electrophoresis and by the TUNEL method. Quantitative analyses by Annexin V-PI staining revealed that Radix Rubiae-induced apoptosis was dose- and timedependent. Furthermore, Radix Rubiae was able to activate caspase- 3 expression when examined by Western blot analysis. The cellular, morphological and molecular data unequivocally demonstrated that induction of cellular apoptosis was mainly responsible for the previously observed anti-proliferation induced Radix Rubiae on HaCaT keratinocytes. Our experimental results suggest that Radix Rubiae is a promising source from which a herb-based topical agent could be developed for psoriasis treatment.
\end{abstract}

\section{Introduction}

Psoriasis is a common chronic inflammatory skin disease that affects, at varying degrees of severity, $\sim 1-3 \%$ of the population worldwide $(1,2)$. Histologically, a typical psoriatic lesion

Correspondence to: Dr Zhi-Xiu Lin, School of Chinese Medicine, 1/F., Sino Building, The Chinese University of Hong Kong, Shatin, N.T., Hong Kong SAR, P.R. China

E-mail: linzx@cuhk.edu.hk

Key words: psoriasis, HaCaT keratinocytes, apoptosis, antiproliferative action, Radix Rubiae features distinct epidermal acanthosis and parakeratosis resulted from hyperproliferation and disturbed differentiation of keratinocytes (3). Among the many essential alterations in the pathophysiology of psoriasis, hyperproliferation and aberrant differentiation of epidermal keratinocytes are two of the fundamental cellular events in the development and maintenance of the disease process. Compounds that inhibit keratinocyte proliferation and modulate keratinocyte differentiation are potentially useful in the treatment of psoriasis because a rebalanced homeostatic control of keratinocyte growth and differentiation is crucial for recovery from psoriatic to normal epidermis. Indeed, many commonly prescribed anti-psoriatic drugs such as dithranol, methotrexate and vitamin D3 analogs exert their therapeutic actions through counteracting keratinocyte hyperproliferation and/or modulating keratinocyte differentiation (4-6); and, to date, identifying safer and more effective anti-proliferative and differentiation-modulating agents on keratinocytes remains an area of active research $(7,8)$.

Given the intrinsic hyperproliferative nature of epidermal cells in psoriatic lesions, it has been postulated that acanthosis of psoriasis is a direct result of diminished apoptotic cell death of keratinocytes, and indeed, resistance of epidermal keratinocytes to apoptosis has been found in psoriatic lesions (9). In addition, the apoptotic index of the basal cell layer in psoriatic epidermis $(0.035 \%)$ is significantly lower than that of healthy skin $(0.12 \%)(10)$. Apoptosis is a physiologic cell death programme that enables the elimination of dysfunctional cells without evoking an inflammatory response. Because of this unique function, apoptosis plays a crucial role in maintaining homeostasis in continually renewing tissues such as skin $(11,12)$, and counterbalances proliferation to maintain epidermal thickness and contributes to normal stratum corneum formation. On the contrary, defects in epidermal apoptosis result in hyperproliferation of keratinocytes, a basic pathogenesis of psoriasis (13). Agents that induce keratinocyte apoptosis can therefore be useful in the treatment of psoriasis.

In our initial study in which 60 medicinal herbs commonly prescribed in traditional Chinese medicine (TCM) to treat psoriasis were investigated using a cultured HaCaT human keratinocyte model, we identified the ethanolic extract of the root of Rubiae Cordifolia L. (Rubiaceae) as possessing potent 
anti-proliferative action with an $\mathrm{IC}_{50}$ value of $1.4 \mu \mathrm{g} / \mathrm{ml}$ (14). Such promising findings on the anti-proliferative properties of Radix Rubiae and the fact that apoptosis is an important mechanism contributing to a reduction of cellular proliferation have prompted us to investigate whether apoptosis is responsible for the observed cellular growth inhibition. This study reports the experimental findings concerning the apoptotic action of Radix Rubiae on cultured HaCaT keratinocytes.

\section{Materials and methods}

Plant material, preparation and quality control of the extract. The raw material of Radix Rubiae was purchased from Zhi-xin Herbal Co. Hong Kong, and authenticated by Dr Yu-ying Zong, an experienced pharmacognosist. A voucher herbarium specimen (Pso no. 61) of the material used in this study was deposited in the Herbarium of the School of Chinese Medicine, The Chinese University of Hong Kong. For preparation of Radix Rubiae extract, the herbal material was ground to powder using an electrical blender. One hundred milliliters $80 \%$ aqueous ethanol was added into $30 \mathrm{~g}$ of the powdered material and sonicated in an ultrasonic bath at $50^{\circ} \mathrm{C}$ for $30 \mathrm{~min}$. The extract was filtered, and the residue was further extracted twice with $80 \%$ aqueous ethanol as before. All three filtrates were combined and concentrated in a rotary evaporator under negative pressure and finally dried in blowing air. The resultant extract $(3.5 \mathrm{~g})$ was stored at $-20^{\circ} \mathrm{C}$ until used.

For quality control of the Radix Rubiae extract, quantitative analysis was performed and high performance liquid chromatography (HPLC) fingerprinting was constructed. Mollugin, a main ingredient present in Radix Rubiae (15), was selected as the chemical marker. The analyses were performed using an Agilent 1100 HPLC system (Agilent, Waldbronn, Germany) equipped with a secondary pump, a diode-array detector (DAD), an autosampler, and a column compartment. The samples were separated on an Alltech Alltima C18 column $(4.6 \times 250 \mathrm{~mm}, 5 \mu \mathrm{m})$. The column temperature was set at $25^{\circ} \mathrm{C}$. The DAD recorded UV spectra in the range of 190-400 nm, and the HPLC chromatogram was monitored at $250 \mathrm{~nm}$. The mobile phase for quantitative analysis was acetonitrile:water (80:20), and was set at a rate of $0.8 \mathrm{ml} / \mathrm{min}$. For fingerprinting, the mobile phase consisted of acetonitrile (A) and water (B), and a gradient programme was used as follows: a linear gradient from $30 \% \mathrm{~A}(\mathrm{~V} / \mathrm{V})$ to $80 \% \mathrm{~A}$ in the first $70 \mathrm{~min}$, then to $100 \%$ A over $10 \mathrm{~min}$, and the flow rate was kept at $1.0 \mathrm{ml} / \mathrm{min}$. For HPLC-MS analysis, an Agilent $1100 \mathrm{LC} / \mathrm{MD}$ trap mass spectrometer was connected to the HPLC system via an APCI interface. Ultra-high-purity helium was used as the collision gas and high purity nitrogen as the nebulizing gas. The optimized parameters in the positive ion mode were as follows: nebulizer gas pressure, 50 psi; dry gas flow, $5.01 / \mathrm{min}$; dry temperature, $350^{\circ} \mathrm{C}$; and vaporizer temperature, $400^{\circ} \mathrm{C}$. For full-scan MS analysis, the spectra were recorded in the range of $\mathrm{m} / \mathrm{z}, 100-500$.

To establish the calibration curve, a stock solution of mollugin was prepared by dissolving the mollugin standard (National Institute for the Control of Pharmaceutical and Biological Products, Beijing, P.R. China) in methanol to a final concentration of $450 \mathrm{mg} / \mathrm{l}$, then the stock was diluted to the appropriate concentrations $(15-450 \mathrm{mg} / \mathrm{l})$. The linearity was established with two injections for each concentration of mollugin to obtain the mean peak area, and the peak areas were plotted against the concentrations. The calibration curve of mollugin thus obtained $(y=30.799 x-60.611)$ had an $R^{2}$ value of 1 , indicating that the quantification of mollugin by this HPLC method was linear in the range of $15-450 \mathrm{mg} / \mathrm{l}$.

General cell culture. Unless otherwise specified, chemicals and reagents used were obtained from Sigma Chemical Co. (Sigma-Aldrich Co. Ltd., USA). HaCaT, an immortalized line of human epidermal keratinocytes (16) which is extensively used as an in vitro model for studies on the pathogenesis of psoriasis (17-19), was provided by the China Centre for Type Culture Collection (CCTCC), Wuhan, P.R. China. Cells were grown in Dulbecco's modified Eagle's medium (DMEM) with $10 \%$ fetal calf serum (Gibco Laboratories, $\mathrm{NY}$, USA), $10 \mu \mathrm{g} / \mathrm{ml}$ of streptomycin and $10 \mathrm{U} / \mathrm{ml}$ of penicillin, and incubated at $37^{\circ} \mathrm{C}$ in a $5 \% \mathrm{CO}_{2} / 95 \%$ air humidified atmosphere.

MTT assay for HaCaT proliferation. The reconstituted Radix Rubiae extract together with $\mathrm{HaCaT}$ cells were cultured in 96-well plates, with each well containing $2 \times 10^{4}$ cells in $200 \mu \mathrm{l}$ DMEM. The final concentrations of the extract ranged from $62.5-0.24 \mu \mathrm{g} / \mathrm{ml}$ by serial doubling dilution. The final concentration of ethanol in all the wells was $<2 \%(\mathrm{v} / \mathrm{v})$, and at such a concentration neither inhibitory nor promoting effect on $\mathrm{HaCaT}$ cell proliferation was observed. The 3-(4,5dimethylthiazol-2-yl)-2,5-diphenyltetrazolium bromide (MTT) assay was carried out as previously described (14). Briefly, MTT was added to the wells at a final concentration of $0.5 \mathrm{mg} / \mathrm{ml}$ and incubated at $37^{\circ} \mathrm{C}$ for $2 \mathrm{~h}$. The medium was then completely removed from the wells and replaced with $100 \mu \mathrm{l}$ DMSO. The absorbance of the dissolved formazan dye was recorded at $540 \mathrm{~nm}$ using a microplate spectrophotometer (Fluostar Optima, BMG Labtechnologies).

Cell cycle analysis with PI staining. Approximately $7.5 \times 10^{5}$ $\mathrm{HaCaT}$ cells seeded on 6-well plates were exposed to Radix Rubiae at $1,8,16$ and $32 \mu \mathrm{g} / \mathrm{ml}$ for 24,48 or $72 \mathrm{~h}$. After being washed in phosphate-buffered saline (PBS), cells were fixed in $70 \%$ ethanol at $4^{\circ} \mathrm{C}$ overnight. The cells were then re-suspended in $10 \mu 1 \mathrm{PI}$ solution $(2 \mathrm{mg} / \mathrm{ml})$ with $50 \mu 1$ RNAase $(10 \mathrm{mg} / \mathrm{ml})$ and incubated in the dark at $37^{\circ} \mathrm{C}$ for $30 \mathrm{~min}$. They were then subjected to DNA content analysis using a FACSort flow cytometer (Becton Dickinson), in which the 'Cell Quest' program was used to analyze the results. Different phases of the cell cycle were assessed by collecting the signal at channel FL2-A. The percentage of the cell population at a particular phase was estimated by ModFit LT for Mac V.3.0 computer programme according to the methods described previously $(20,21)$.

\section{Experiments on Radix Rubiae-induced apoptosis}

Fluorescent staining of HaCaT cells for morphological evaluation. Approximately $7.5 \times 10^{5} \mathrm{HaCaT}$ cells were seeded in 6-well plates. The cells were treated with $16 \mu \mathrm{g} / \mathrm{ml} \mathrm{Radix}$ Rubiae for $48 \mathrm{~h}$ and then washed with PBS and fixed in $4 \%$ 
paraformaldehyde for $30 \mathrm{~min}$. Subsequently, they were stained with $20 \mu \mathrm{g} / \mathrm{ml}$ Hoechst 33342 (Molecular Probes, USA) for $15 \mathrm{~min}$ at room temperature in the dark. Morphological changes in the Radix Rubiae-treated cells were evaluated using an inverted fluorescent microscope (Olympus) according to the method described previously (22).

DNA fragmentation assay. A million $\mathrm{HaCaT}$ cells were seeded on 100-mm plates and exposed to 2, 4, 8, 16 and $32 \mu \mathrm{g} /$ ml Radix Rubiae extract for 24, 48 and 72 h. After harvest, cells were lysed in $200 \mu \mathrm{l}$ of DNA lysis buffer at $37^{\circ} \mathrm{C}$ for $15 \mathrm{~min}$. The supernatant was sequentially incubated with $10 \mu 1 \mathrm{RNase}(4 \mathrm{mg} / \mathrm{ml})$ and then with $20 \mu 1$ proteinase $\mathrm{K}(1.5$ $\mathrm{mg} / \mathrm{ml})$ at $56^{\circ} \mathrm{C}$ for $1.5 \mathrm{~h}$. The DNA of the cells was then precipitated with sodium acetate and centrifuged at $20,000 \mathrm{x} \mathrm{g}$ for $30 \mathrm{~min}$. Finally, $30 \mu \mathrm{l}$ of Tris-EDTA buffer was added to the sample and incubated at $37^{\circ} \mathrm{C}$ for $30 \mathrm{~min}$. To analyze the fragmented DNA, $10 \mu 1$ of the extracted cellular DNA was electrophoresed on a $1.5 \%$ agarose gel, and DNA ladders in the gels were visualized under UV light after staining with ethidium bromide.

TUNEL assay. To further analyze DNA fragmentation, the terminal deoxynucleotidyl transferase biotin-dUTP nick end labeling (TUNEL) assay in which DNA strand breaks can be detected by enzymatic labeling of the free 3'-OH termini with modified nucleotides was employed using methods described previously (23-25). Briefly, $7.5 \times 10^{5}$ $\mathrm{HaCaT}$ cells were seeded on a 6 -well plate and exposed to $14 \mu \mathrm{g} / \mathrm{ml}$ of Radix Rubiae extract at $37^{\circ} \mathrm{C}$ for $36 \mathrm{~h}$. Cells were then fixed in $2 \%$ paraformaldehyde for $1 \mathrm{~h}$ and permeabilised with $0.1 \%$ Triton $\mathrm{X}-100$ at $4^{\circ} \mathrm{C}$ for $2 \mathrm{~min}$. The cells were then incubated at $37^{\circ} \mathrm{C}$ in the dark for $1 \mathrm{~h}$ with $50 \mu 1$ TUNEL reaction mixture provided with the In Situ Cell Death Detection kit (Roche Applied Science, Philadelphia, PA, USA). Finally, cells were re-suspended in $0.5 \mathrm{ml}$ PBS and analyzed by FACSort flow cytometry (Becton Dickinson).

Quantitative analysis of apoptotic cells by Annexin V staining. In our experiments, $7.5 \times 10^{5} \mathrm{HaCaT}$ cells were seeded on 6-well plates and incubated with Radix Rubiae at $1,8,16$ and $32 \mu \mathrm{g} / \mathrm{ml}$ for 24,48 or $72 \mathrm{~h}$. Trypsinized cells were pooled together and stained concomitantly with Annexin V and PI. The Annexin V used was a chimeric recombinant protein produced by fusing green fluorescent protein (GFP) to the N-terminus of Annexin V (26). The stained cells were subsequently analyzed by flow cytometry (Becton Dickinson). The signal was detected by FL1 and FL3 channels, and quadrant markers were set on dotplots of unstained and stained cells.

Western blot analysis of caspase-3. A million cells seeded on each 100-mm plate were exposed to Radix Rubiae extract at $1,8,16$ and $32 \mu \mathrm{g} / \mathrm{ml}$ for 24,48 and $72 \mathrm{~h}$. Cells removed from the culture plates by scraping were lysed with lysis buffer for $3 \mathrm{~h}$, and the resultant lysates were boiled for $10 \mathrm{~min}$. The supernatant was collected and stored at $-20^{\circ} \mathrm{C}$. The protein concentrations were measured with the Bicinchoninic acid protein assay kit. Equal amounts of protein were resolved by sodium dodecyl sulfate-polyacrylamide gel electrophoresis (SDS-PAGE) on a $15 \%$ gel. Separated proteins were then electro-transferred onto a PVDF membrane (Bio-Rad, Hercules, USA), which was then blocked with $10 \%$ non-fat milk. Next the membrane was sequentially probed with the primary anti-caspase- 3 antibody (Calbiochem, La Jolla, CA) and then with the secondary peroxidase-conjugated goat anti-rabbit IgG antibody (Santa Cruz, CA, USA). The immunoreactive bands were visualized with an ECL Western blotting detection kit (Amersham Life Sciences, Sydney, Australia) on light sensitive films (AGFA). Rainbow molecular weight markers were used as size markers for the determination of protein size.

Statistical analysis. Data were expressed as the means \pm SEM. Statistical comparisons between Radix Rubiae treatment and control were carried out using one-way analysis of variance (ANOVA), followed by the post-hoc Dunnett's test using the drug-free treatment as the control group on the SPSS for Windows (version 14.0). Differences were considered significant at $\mathrm{p}<0.05$.

\section{Results}

Quality control of the Radix Rubiae extract. Fig. 1 shows the overlapped HPLC chromatograms of mollugin in the standard solution and that present in the Radix Rubiae extract. The content of mollugin present in the Radix Rubiae extract was calculated to be $2.774 \%$. The HPLC fingerprinting of Radix Rubiae extract was established and is shown in Fig. 2. The mollugin peak in the chromatogram of the extract sample was identified by comparing its retention time, UV absorption profile and HPLC-MS result with those of the mollugin standard solution. The established HPLC fingerprinting can be employed as a reference for the purpose of quality assurance for any future experiments on this herbal extract.

Action of Radix Rubiae on HaCaT cell proliferation. The anti-proliferative action of Radix Rubiae on the cultured HaCaT keratinocytes as determined by MTT assay is shown in Fig. 3. It is evident that the Radix Rubiae extract exerted potent anti-proliferative action on the $\mathrm{HaCaT}$ keratinocytes in a dose- and time-dependent manner. The $\mathrm{IC}_{50}$ values were $>62.5,18.3,11.9,5.8,1.4$ and $2.9 \mu \mathrm{g} / \mathrm{ml}$ when the cells were exposed to Radix Rubiae extract for 3, 6, 12, 24, 48 and $72 \mathrm{~h}$, respectively. These results are in general agreement with our previous findings regarding the growth inhibitory effect of Radix Rubiae on HaCaT keratinocytes (14).

Action of Radix Rubiae on cell cycle progression. The flow cytometric measurement of propidium iodide (PI)-stained DNA is shown in Fig. 4a and b. Radix Rubiae extract at the concentrations tested was capable of inducing the sub-G1 phase. The appearance of the sub-G1 phase is indicative of the occurrence of apoptosis. After $48 \mathrm{~h}$ of treatment with the extract, the amount of cells in sub-G1 phase increased from 0.3 to $15.2 \%$ when the concentration was increased from 1 to $32 \mu \mathrm{g} / \mathrm{ml}$ (Fig. 4c). Also, the sub-G1 population gradually increased from 3.3 to $34.3 \%$ when the incubation time was extended from $24-72 \mathrm{~h}$ in the presence of $32 \mu \mathrm{g} / \mathrm{ml}$ Radix Rubiae extract (Fig. 4d). Moreover, apart from the induction of the sub-G1 peak, Radix Rubiae also altered the cell cycle distribution of the cultured $\mathrm{HaCaT}$ cells. After treatment for $48 \mathrm{~h}$ with $32 \mu \mathrm{g} / \mathrm{ml}$ of Radix Rubiae extract, the percentage of 


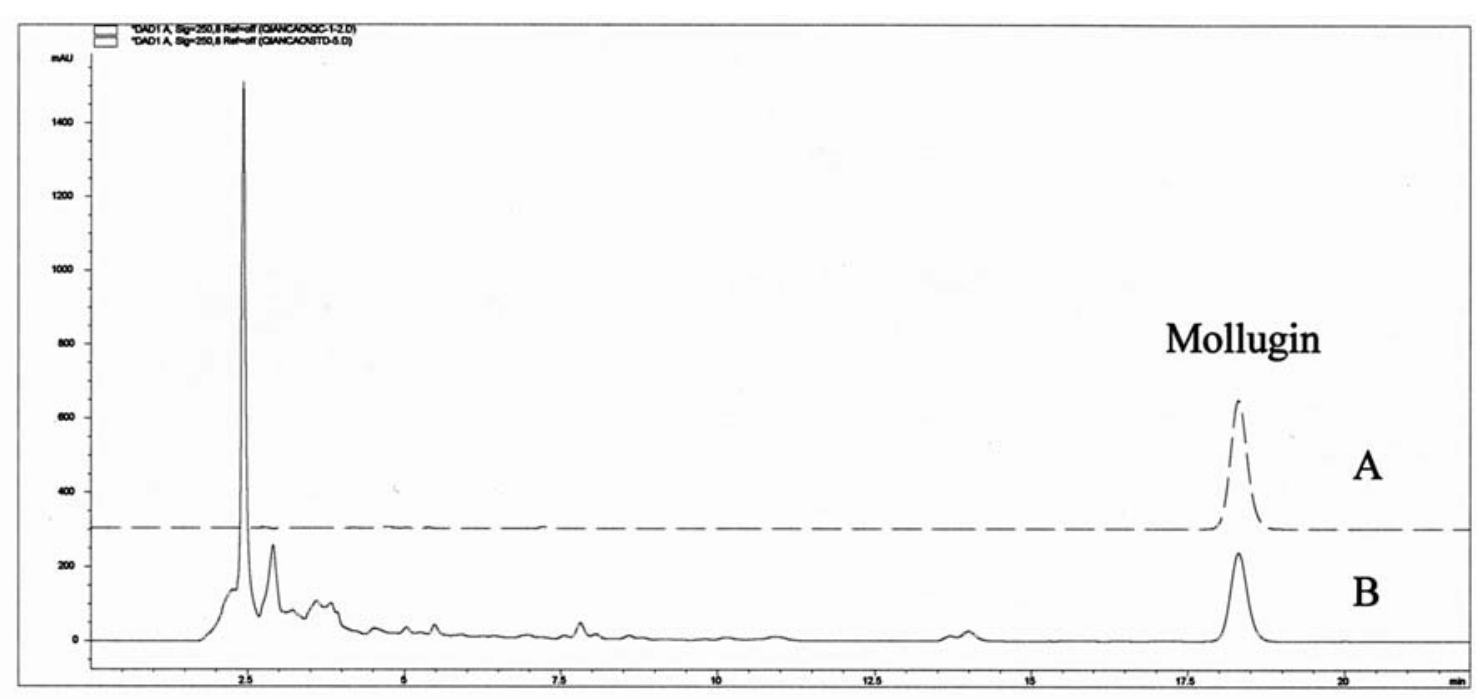

Figure 1. Overlapped HPLC chromatograms for quantitative analysis of mollugin in the standard and Radix Rubiae extract solutions. Chromatographic conditions: column, 4.6x250 mm I.D., packed with C18 $(5 \mu \mathrm{m})$; column temperature, $25^{\circ} \mathrm{C}$; flow rate, $0.8 \mathrm{ml} / \mathrm{min}$; mobile phase, acetonitrile-water $(80: 20)$; and UV detection wavelength, $250 \mathrm{~nm}$. Chromatogram A and B denote the mollugin standard and the Radix Rubiae ethanolic extract, respectively.

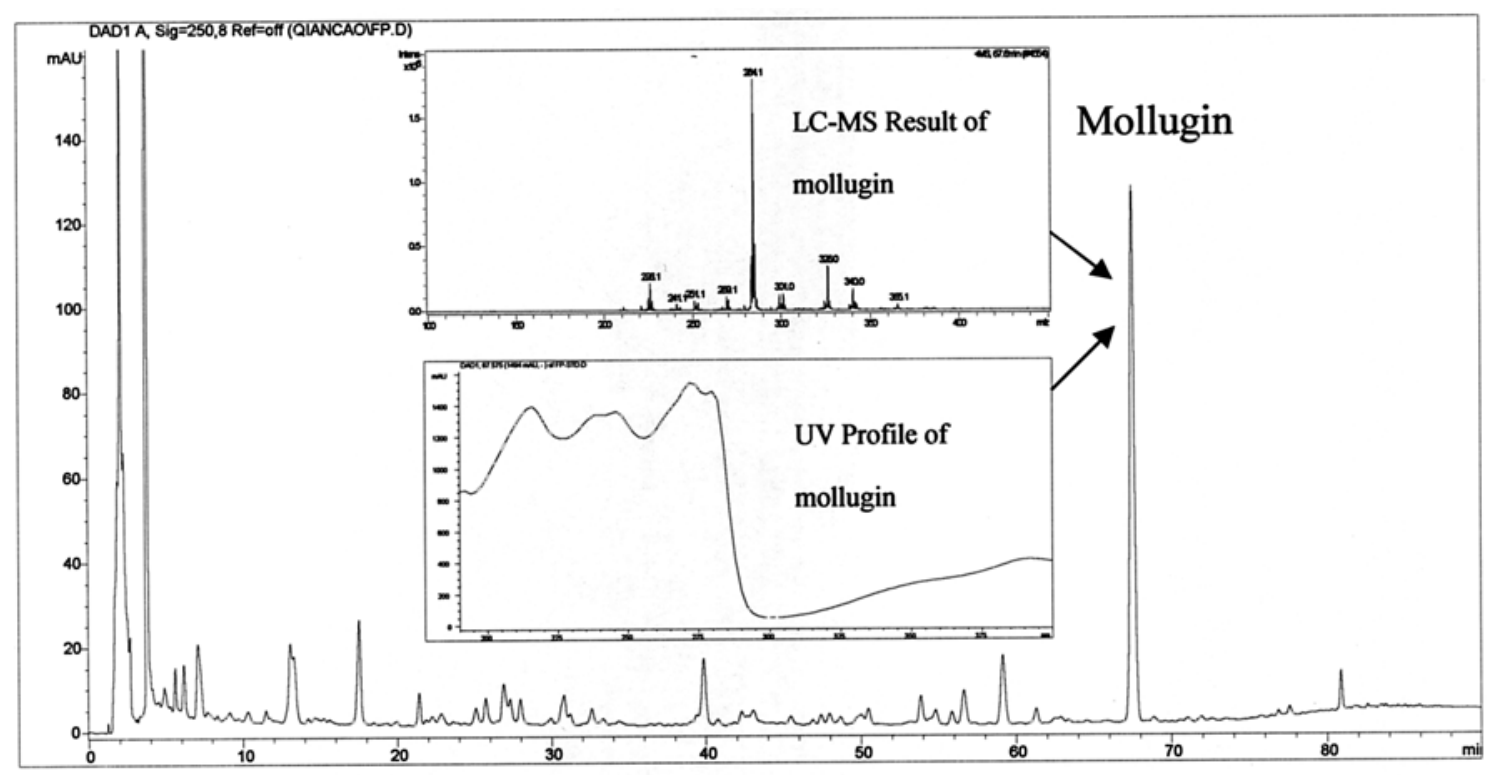

Figure 2. HPLC fingerprinting of Radix Rubiae extract. Chromatographic conditions: column, 4.6x250 mm I.D., packed with C18 (5 $\mu \mathrm{m})$; column temperature, $25^{\circ} \mathrm{C}$; UV detection wavelength, $250 \mathrm{~nm}$; and flow rate, $1.0 \mathrm{ml} / \mathrm{min}$. The mobile phase consisted of acetonitrile and water with a linear gradient from $30 \%$ acetonitrile (v/v) to $80 \%$ acetonitrile in the first $70 \mathrm{~min}$, then to $100 \%$ acetonitrile over $10 \mathrm{~min}$. The peak of mollugin was identified by comparing its retention time $\left(\mathrm{t}_{\mathrm{R}}, 67.5 \mathrm{~min}\right)$, UV absorption profile $\left(\lambda_{\max }, 216,250,272,280 \mathrm{~nm}\right)$, and APCIMS data $\left(\mathrm{M}^{+}, \mathrm{m} / \mathrm{z}, 284\right)$ with those of the standard sample. For full-scan MS analysis, the mass spectra were recorded in the range of $m / z, 100-500$.

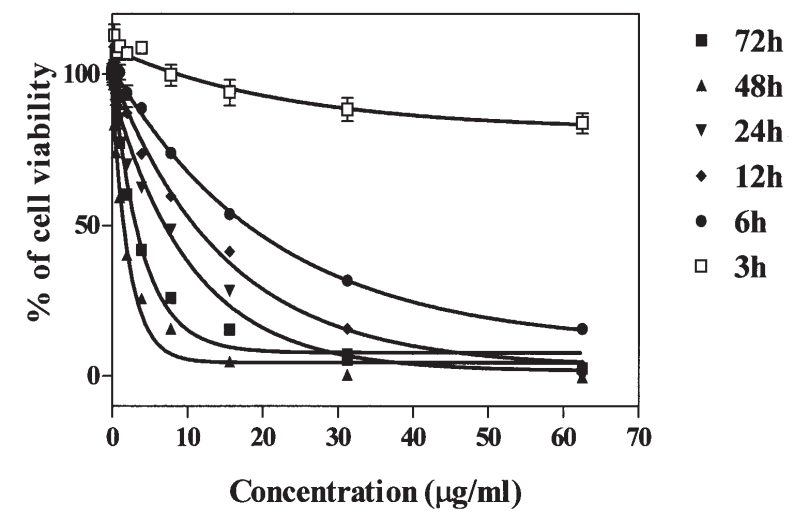

Figure 3. Anti-proliferative action of Radix Rubiae extract on cultured $\mathrm{HaCaT}$ cells. HaCaT cells were treated with various concentrations of Radix Rubiae extract and incubated for $3,6,12,24,48$ and $72 \mathrm{~h}$, followed by the MTT assay. $\mathrm{IC}_{50}$ values were determined as $>62.5,14.9,10.5,7.4,1.6$ and $2.8 \mu \mathrm{g} / \mathrm{ml}$, respectively using a GraphPad Prism 3.0 computer programme. The values shown are the mean \pm SEM with $n=6$. 
a

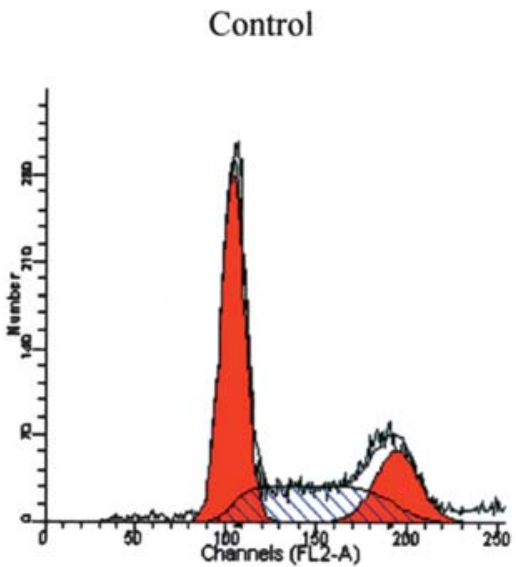

c

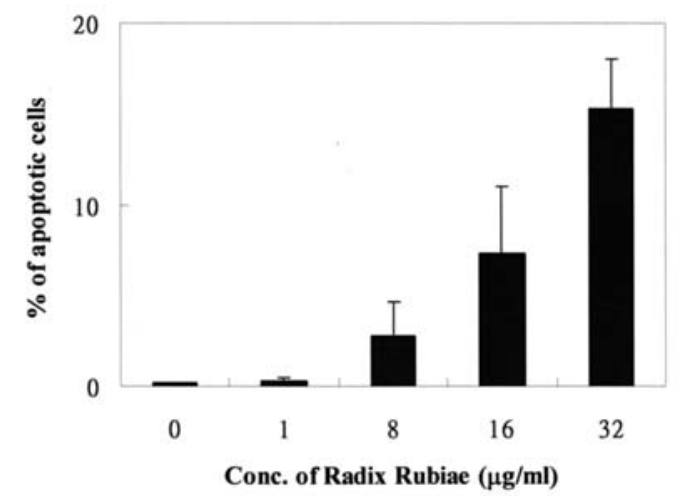

b $\quad 32 \mu \mathrm{g} / \mathrm{ml}$ Radix Rubiae extract

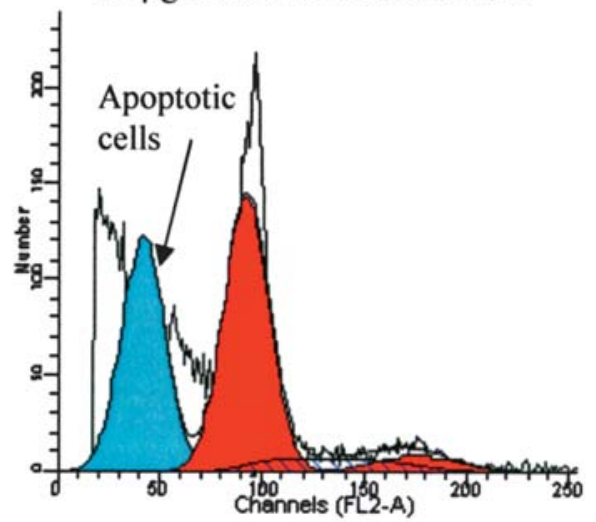

d

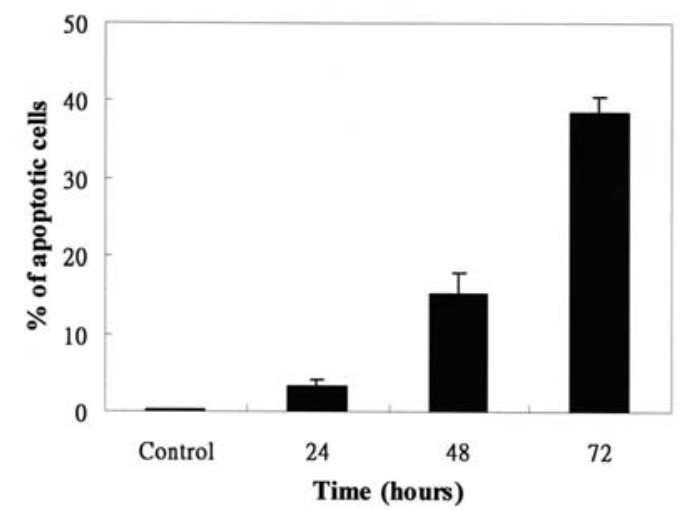

Figure 4. Flow cytometric analysis of cell cycle distribution of cultured HaCaT keratinocytes with PI staining. (a) Drug- free control only. (b) Cells treated with $32 \mu \mathrm{g} / \mathrm{ml}$ of Radix Rubiae extract for $72 \mathrm{~h}$. Note the appearance of sub-G1 phase upon treatment with Radix Rubiae. (c) Dose-dependent action of Radix Rubiae on the induction of sub-G1 phase on HaCaT keratinocytes. HaCaT cells were cultured for 48 h. (d) Time-dependent effect of Radix Rubiae on the induction of sub-G1 phase on HaCaT keratinocytes. HaCaT cells were cultured in the presence of $32 \mu \mathrm{g} / \mathrm{ml}$ Radix Rubiae extract. The values shown in c and $\mathrm{d}$ are the mean \pm SEM with $\mathrm{n}=3$.

$\mathbf{a}$

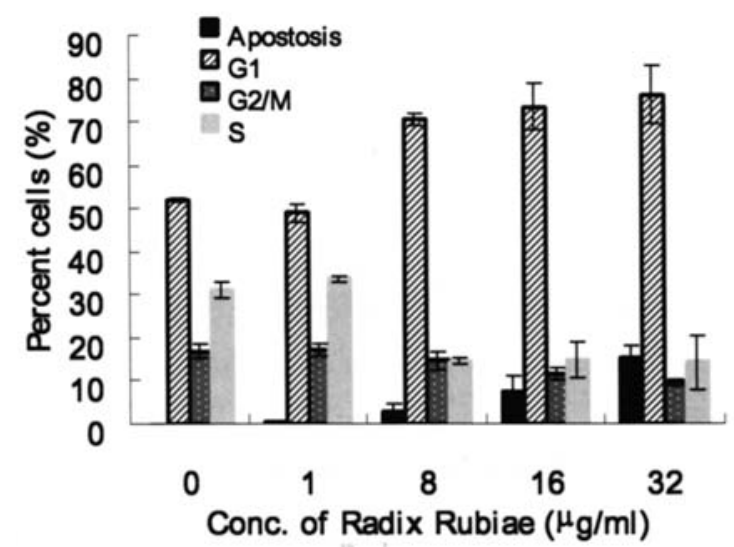

b

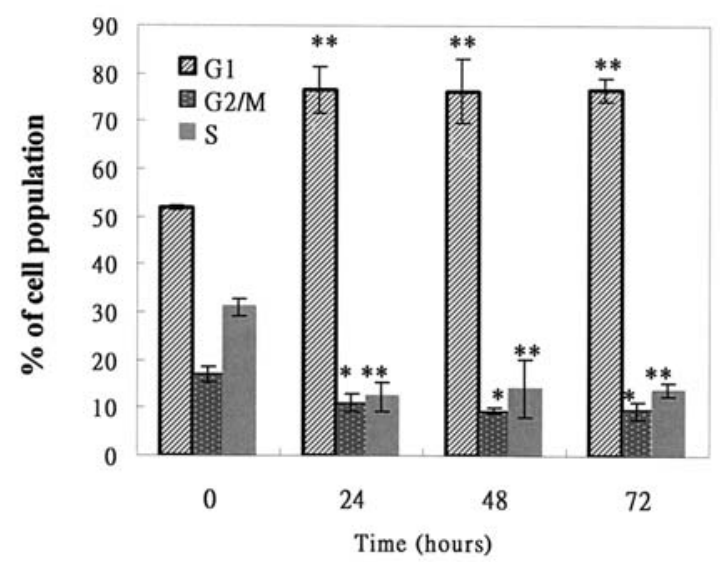

Figure 5. Distribution of the cell cycle of HaCaT keratinocytes under the influence of Radix Rubiae. (a) Cells were exposed to different concentrations of Radix Rubiae extract for $48 \mathrm{~h}$ followed by flow cytometric analysis with PI staining. (b) Cells were treated with $32 \mu \mathrm{g} / \mathrm{ml}$ Radix Rubiae extract for 24,48 and $72 \mathrm{~h}$, respectively. The values shown are the mean $\pm \mathrm{SEM}$, with $\mathrm{n}=3 .{ }^{*} \mathrm{p}<0.05$ and ${ }^{* *} \mathrm{p}<0.01$ when compared with the drug-free control.

cells in $\mathrm{G} 1, \mathrm{~S}$ and $\mathrm{G} 2 / \mathrm{M}$ phases changed from 52.0, 31.1 and $16.9 \%$ to $76.3,14.2$ and $9.5 \%$, respectively (Fig. 5a). Furthermore, when exposed to longer time periods, the percentage of cells in the G1 phase increased markedly, while $\mathrm{S}$ and $\mathrm{G} 2 / \mathrm{M}$ phases decreased accordingly (Fig. 5b). Taken together, the results from our experiments indicated that Radix Rubiae induces HaCaT cell arrest at the G1 phase.

\section{Action of Radix Rubiae on induction of apoptosis}

Alteration of cellular morphology. After exposure to Radix Rubiae for $48 \mathrm{~h}$, a greater number of cells showed detachment from the culture plate when compared to the drug-free control (Fig. 6a and b). In addition, compared with the Hoechst-stained normal HaCaT keratinocytes (Fig. 6c), the Hoechst-stained HaCaT keratinocytes after exposure to 
a

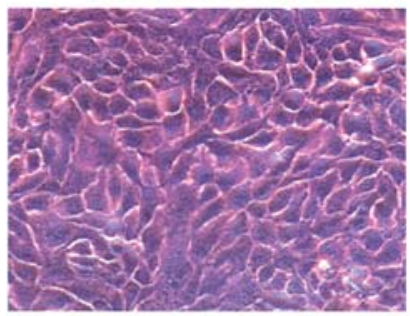

b

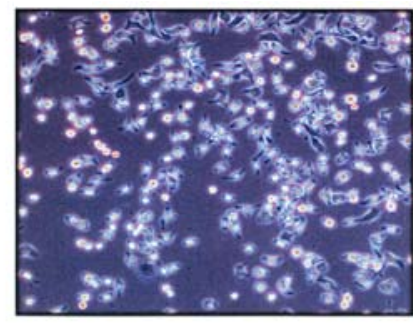

c

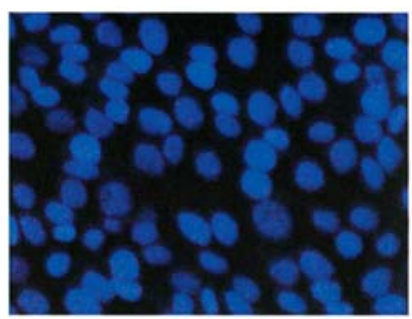

d
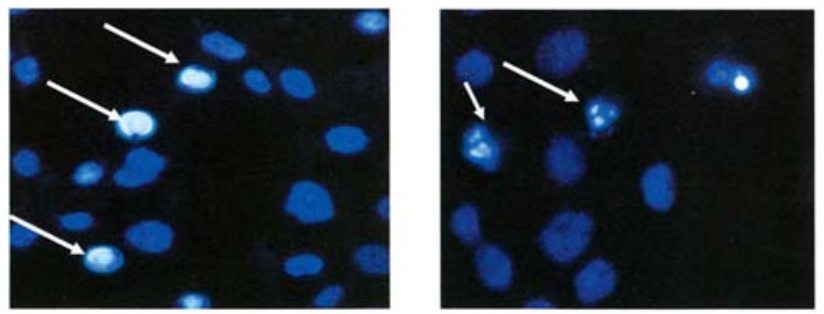

Figure 6. Action of Radix Rubiae on HaCaT morphology as examined by phase contrast microscopy. (a) Normal HaCaT cells. (b) HaCaT cells treated with $16 \mu \mathrm{g} / \mathrm{ml}$ Radix Rubiae extract for $48 \mathrm{~h}$. (c) Normal HaCaT cells stained with Hoesch 33342. (d,e) HaCaT cells treated with $16 \mu \mathrm{g} / \mathrm{ml}$ Radix Rubiae for $36 \mathrm{~h}$ and stained with Hoesch 33342. Arrows point to the cells with chromatin condensation (d) and DNA fragmentation (e).

$16 \mu \mathrm{g} / \mathrm{ml}$ Radix Rubiae extract for $48 \mathrm{~h}$ appeared to be shrunken and displayed fewer intercellular connections and showed typical apoptotic morphology characterized by chromatin condensation (Fig. 6d) and DNA fragmentation (Fig. 6e).

Detection of DNA fragmentation. Detection of DNA laddering on electrophoresis was used to confirm the morphological findings regarding the apoptotic action of Radix Rubiae. In Fig. 7a, DNA laddering was clearly evident with treatment of a higher concentration of Radix Rubiae for $48 \mathrm{~h}$. In Fig. 7b, the laddering pattern of nucleosome monomer and oligomers was clearly distinguishable only after 48 and $72 \mathrm{~h}$ of incubation, but not at $24 \mathrm{~h}$. The results indicated that the occurrence of cellular DNA fragmentation mediated by Radix Rubiae was dose- and time-related. The TUNEL assay constitutes another method to detect the fragmented DNA by identifying apoptotic cells in situ using terminal deoxynucleotidyl transferase to transfer biotin-dUTP to these strand breaks of cleaved DNA. DNA strand breaks can be detected by enzymatic labeling of the free 3'-OH terminal with modified nucleotides. Compared to the control in Fig. 8a, $\mathbf{a}$

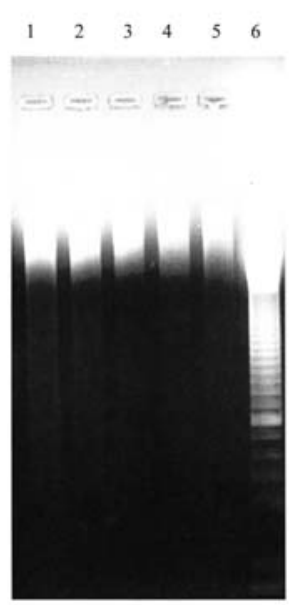

b

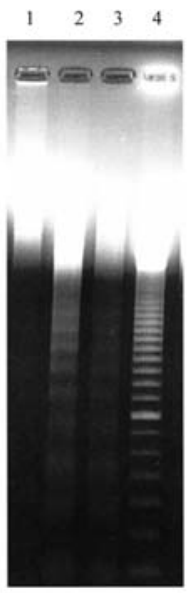

Figure 7. Action of Radix Rubiae on DNA fragmentation on HaCaT cells. (a) Lanes 1 to 6 are Radix Rubiae extract at 32,16,8,4,2 $\mu \mathrm{g} / \mathrm{ml}$ and the 100-base-pair marker, respectively; incubation time, $48 \mathrm{~h}$. Note that the laddering pattern was clearly developed at $32 \mu \mathrm{g} / \mathrm{ml}$ Radix Rubiae extract. (b) Lanes 1 to 4 correspond to an incubation of $32 \mu \mathrm{g} / \mathrm{ml}$ Radix Rubiae extract for $24,48,72 \mathrm{~h}$ and the 100-base-pair marker, respectively. Note that the laddering pattern was clearly observed at 48 and $72 \mathrm{~h}$, but not at $24 \mathrm{~h}$.

Fig. 8b clearly shows the apoptotic peaks of HaCaT cells when treated with Radix Rubiae.

Quantitative analysis of apoptotic cells by Annexin V-PI staining. Early in apoptosis, phosphatidylserine (PS) is translocated from the inner to the outer surface of the plasma membrane. PS exposure, therefore, represents a useful target for evaluating apoptosis (27-29). The translocation of PS from the inner to the outer surface of the plasma membrane during apoptosis can be detected by Annexin $\mathrm{V}$ which binds preferentially to PS in the presence of $\mathrm{Ca}^{2+}$. To assess plasma membrane changes, cells were stained with Annexin-V and PI simultaneously. The combination of staining with Annexin-V and PI which does not diffuse through intact cell membranes allows discrimination between, and quantification of, apoptotic, necrotic and viable cells. As shown in Fig. 9, the viable, apoptotic and necrotic cells were localized in the lower left, the lower right, and the upper right quadrant, respectively. When exposed to lower concentrations of the extract, the majority of cells were localized in the lower left quadrant, indicative of an absence of overt cell death. As the concentration of Radix Rubiae increased from 1 to $32 \mu \mathrm{g} / \mathrm{ml}$, the percentage of apoptotic cells was significantly elevated from 3.5-49.4\%; and accordingly, the percentage of viable cells decreased from 87.1 to $31.3 \%$ after $48 \mathrm{~h}$ of drug treatment (Fig. 10a). Since apoptotic cells in vitro will eventually undergo 'secondary necrosis', the percentage of necrotic cells thus increased from 9.5 to $21.9 \%$. Likewise, the percentage of apoptotic cells markedly increased from 23.3 to $60 \%$ and the viable cells significantly decreased from 56.2 to $12.0 \%$ as the incubation time was extended from 24 to $72 \mathrm{~h}$ in the presence of $32 \mu \mathrm{g} / \mathrm{ml}$ Radix Rubiae. However, the percentage of necrotic cells did not change significantly (Fig. 10b). These results unambiguously demonstrated that induction of cellular apoptosis is mainly responsible for the Radix Rubiae-mediated $\mathrm{HaCaT}$ keratinocyte growth inhibition, and the apoptotic action of this herb is dose- and time-dependent. 

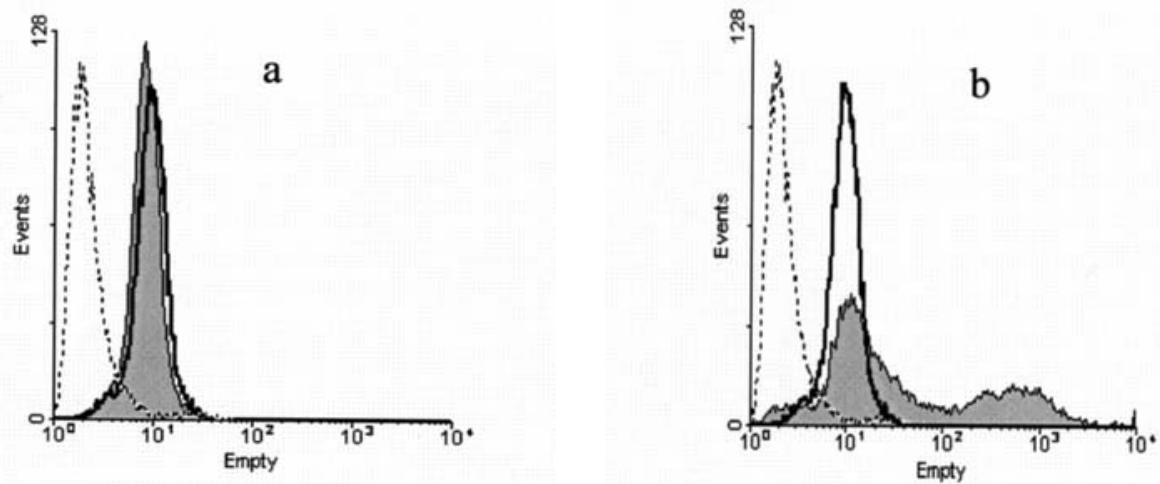

Figure 8. TUNEL analysis of Radix Rubiae-induced apoptosis in HaCaT cells. (a) Cells cultured in the absence of the herbal extract. (b) Cells cultured in the presence of $14 \mu \mathrm{g} / \mathrm{ml}$ Radix Rubiae extract for $36 \mathrm{~h}$. (---) Control for autofluorescence of cells in the absence of label or enzyme solution. (-) Drug-free control incubated with label solution. Grey shading indicates cells incubated with TUNEL reaction mixture containing both label and enzyme solutions.

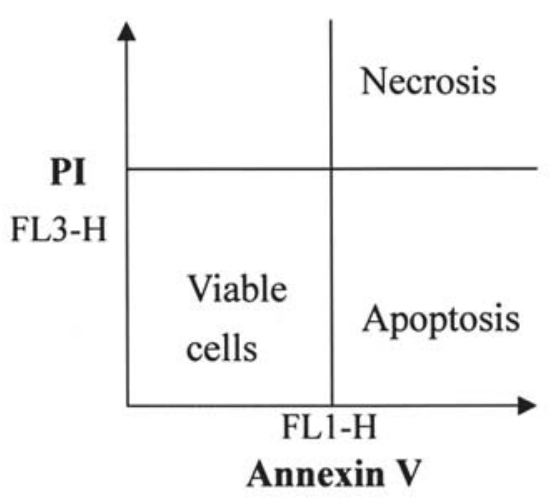

$8 \mu \mathrm{g} / \mathrm{ml}$

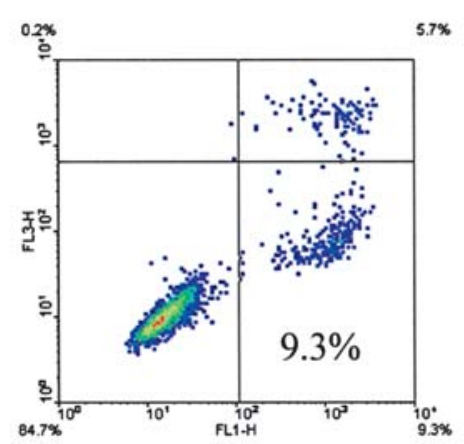

Control

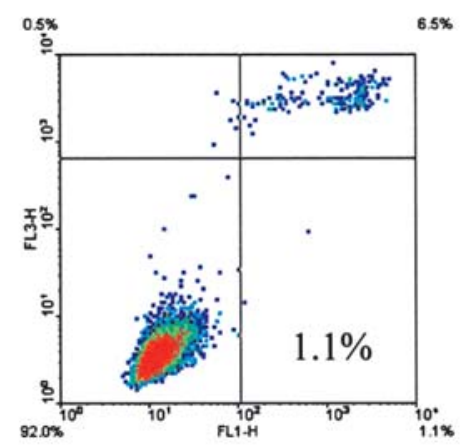

$1 \mu \mathrm{g} / \mathrm{ml}$

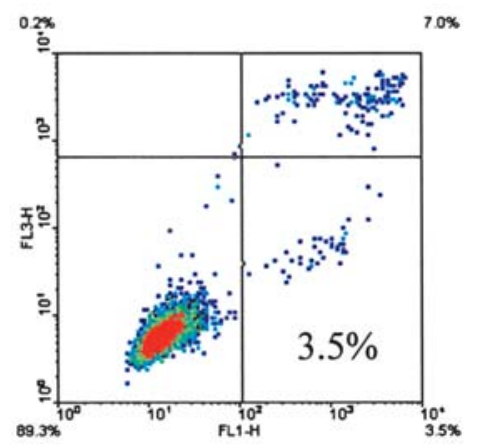

$16 \mu \mathrm{g} / \mathrm{ml}$

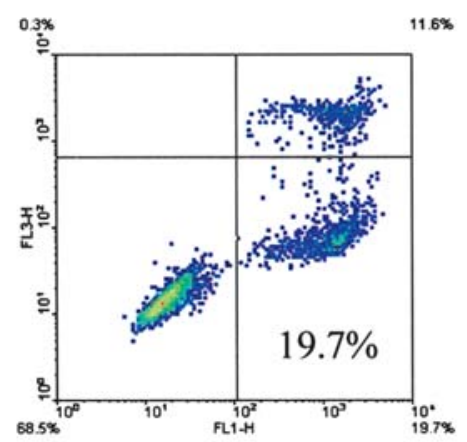

$32 \mu \mathrm{g} / \mathrm{ml}$

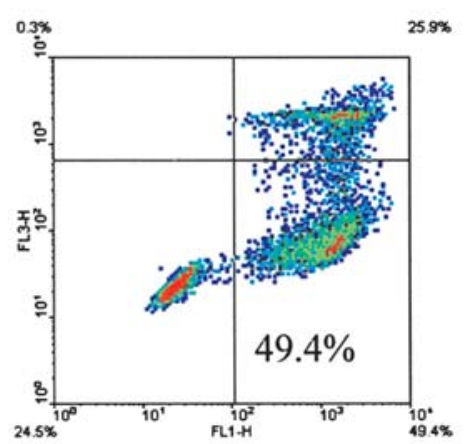

Figure 9. Quantitative analysis of Radix Rubiae-induced apoptosis by Annexin V-PI binding assay. Figures show the distribution of apoptotic cells in the total $\mathrm{HaCaT}$ cell population in the presence of Radix Rubiae extract $(1,8,16$ and $32 \mu \mathrm{g} / \mathrm{ml})$ for $48 \mathrm{~h}$ followed by labeling with Annexin V and PI and analysis by flow cytometry.

Western blot analysis. Caspase-3 is the apoptosispromoting enzyme responsible for cleaving cellular substrates leading to the characteristic cellular morphological alterations. The results of caspase- 3 activation by different concentrations of Radix Rubiae extract are shown in Fig. 11a. Radix Rubiae was able to significantly increase the activity of caspase- 3 (19 and $17 \mathrm{kDa}$ ) and decrease procaspase-3 (32 kDa) in a dose-dependent manner. Likewise, in the presence of $32 \mathrm{mg} /$ $\mathrm{ml}$ Radix Rubiae, the expression of procaspase- 3 decreased and the activation of caspase- 3 increased as the exposure time was extended (Fig. 11b). These results demonstrated that the underlying mechanism of Radix Rubiae-induced apoptosis in $\mathrm{HaCaT}$ cells involves the cleavage of procaspase- 3 into the activated form of caspase-3.

\section{Discussion}

The maintenance of normal epidermal architecture is the result of a delicate balance between proliferation of cells in the basal cell layer and the death of keratinocytes in the 
$\mathbf{a}$

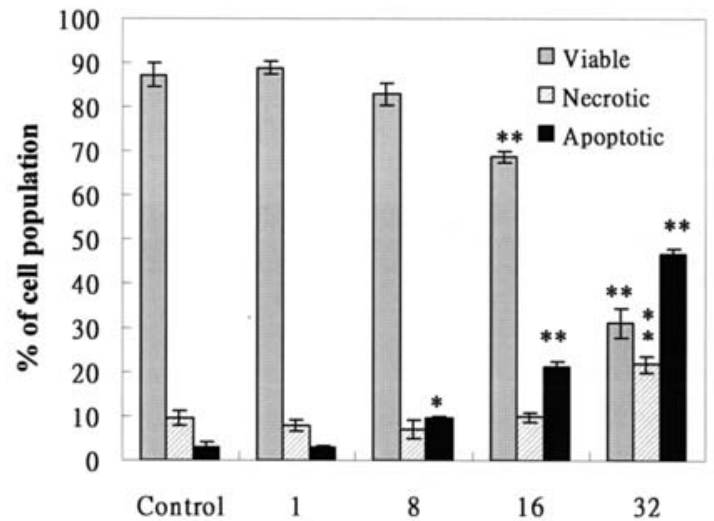

Conc. of Radix Rubiae $(\mu \mathrm{g} / \mathrm{ml})$ b

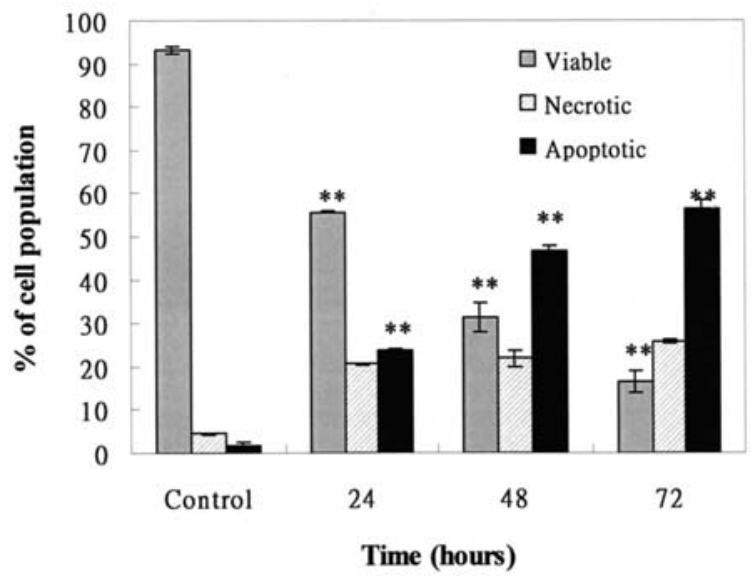

Figure 10. Distribution of viable, apoptotic and necrotic HaCaT keratinocytes in the presence of Radix Rubiae extract. (a) Bar chart presentation of the distribution of viable, apoptotic and necrotic cell populations after treatment with Radix Rubiae. (b) Bar chart presentation of time course effect on the distribution of viable, apoptotic and necrotic cell in the presence of $32 \mu \mathrm{g} / \mathrm{ml}$ Radix Rubiae extract. The values shown represent the mean $\pm \mathrm{SEM}$ with $\mathrm{n}=3$. ${ }^{*} \mathrm{p}<0.05$ and $^{* *} \mathrm{p}<0.01$ when compared with the drug-free control.

a

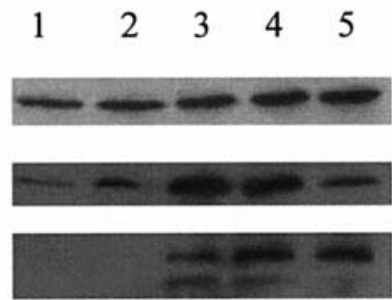

b

\section{$\beta$-actin \\ $32 \mathrm{kDa}$}

$19 \& 17 \mathrm{kDa}$

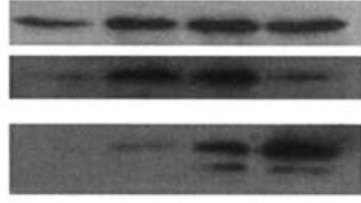

$\beta$-actin

$32 \mathrm{kDa}$

$19 \& 17 \mathrm{kDa}$

Figure 11. Western blot analysis of the Radix Rubiae-induced expression of caspase-3. (a) Lanes 1 to 5 correspond to control, 1,8 , 16 , and $32 \mu$ g/ml of Radix Rubiae extract, respectively. (b) Lanes 1 to 4 correspond to the incubation time of 0,24 , 48, and $72 \mathrm{~h}$, respectively in the presence of $32 \mu \mathrm{g} / \mathrm{ml}$ Radix Rubiae extract. Note that the band sizes 19 and $17 \mathrm{kDa}$ are activated caspase- 3 , and band size $32 \mathrm{kDa}$ is procaspase- 3 .

superficial layer of the epidermis mainly through apoptosis. Epidermal hyperplasia and abnormal keratinization are two characteristic cellular events in psoriasis. Hyperproliferation of epidermal keratinocytes is the result of the aberrant expression of many regulatory molecules associated with proliferation, but defects in apoptosis are believed to play an important role in the pathogenesis of psoriasis (30). Data from in vitro studies have shown that human keratinocytes derived from psoriatic lesions are resistant to induced apoptosis compared to keratinocytes derived from normal skin (9). Moreover, induction of apoptosis of keratinocytes has been suggested to be responsible for the regression of psoriatic hyperplasia resulting in long-lasting clinical remissions after UVB phototherapy (31). Other established anti-psoriatic therapies such as dithranol and vitamin D3 analogs exert their therapeutic actions through induction of keratinocyte apoptosis $(32,33)$. Agents that are able to inhibit keratinocyte proliferation and induce keratinocyte apoptosis therefore possess good potential for being developed into effective agents for treating psoriasis.

In our previous as well as the present study, the extract of the root of Rubiae Cordifolia consistently showed very potent inhibitory action on the proliferation of cultured HaCaT keratinocytes. As an indigenous Chinese medicinal herb, the therapeutic properties and applications of Radix Rubiae were first recorded in the Divine Husbandman's Classic of Materia Medica, the earliest book on Chinese herbal medicine written $\sim 2,000$ years ago. Today, Radix Rubiae remains a commonly prescribed herb in Chinese herbal medicine practice principally for febrile and bleeding conditions (34). During the past several decades, this herb has attracted much attention, and several chemical classes of compounds have been identified in this herb including anthraquinones, naphthohydroquinones, cyclic hexapeptides, and polysaccharides (35). Pharmacologically, Radix Rubiae and its isolated constituents have been revealed to possess a wide spectrum of biological activities including anti-oxidant, immunosuppressive, haemostatic, white blood cell countboosting and anticancer properties (35). More recently, in a screening programme aimed at evaluating the anti-psoriatic properties of Chinese herbal medicines, our research group identified this herb to possess potent anti-proliferative action on human keratinocytes. The elucidation of the underlying cellular and biochemical mechanisms for the observed growth inhibitory action is necessary for this bioactive herbal extract to be developed as an effective therapy for psoriasis treatment. In the present study, experiments were designed to elucidate at the morphological, molecular and biochemical 
levels to assess whether induction of cellular apoptosis is responsible for the Radix Rubiae-mediated growth inhibition on human keratinocytes. It is worth noting that the Radix Rubiae extract used in the present study was properly standardized. Considering that the bioactive constituents are still not well understood, and most possibly multiple constituents are involved in the pharmacological action, we therefore chose to quantify the major constituent, mollugin (commercially available), and to construct the HPLC fingerprinting of the extract. The concentration of mollugin and the characteristics of fingerprinting can present the quality index of the extract and make it possible to ensure a batch-to-batch consistency of the extract in future studies.

Cell cycle progression analysis by flow cytometry revealed that Radix Rubiae significantly increased the population of $\mathrm{HaCaT}$ cells in the sub-G1 phase (apoptotic peak) while reducing the number of cells in the $\mathrm{G} 2 / \mathrm{M}$ and $\mathrm{S}$ phases. This result suggests that Radix Rubiae induces cell cycle arrest at the G1 phase, thereby causing apoptosis. Morphologically, apoptosis is characterized by membrane blebbing and DNA fragmentation in individual cells. Radix Rubiae-treated $\mathrm{HaCaT}$ cells were found to have hypercondensed nuclei and DNA fragmentation when stained with the Hoechst stain followed by observation under the microscope. DNA cleavage is a biochemical hallmark of apoptosis, and assays which measure prelytic DNA fragmentation are especially useful for the determination of apoptotic cell death (36). Electrophoresis of fragmented DNA can provide clear evidence of DNA laddering $(37,38)$. In our experiments, Radix Rubiae induced DNA fragmentation as illustrated by gel electrophoresis. Using the TUNEL method, we further demonstrated that DNA strand breaks were induced in the HaCaT cells by Radix Rubiae.

The discrimination between apoptotic and necrotic cells was achieved by quantitatively estimating the relative amount of the Annexin V-and PI-stained cells in the population. The results from quantitative analysis of apoptotic cells by concomitant Annexin V-PI staining also revealed that Radix Rubiae induced apoptosis of the HaCaT keratinocytes in a time- and concentration-dependent manner. The physical destruction of the cell occurring during apoptosis is mediated by a class of enzymes called caspases, or cysteine proteases, which are responsible for the cleavage of specific protein substrates at an amino acid position immediately following an aspartic acid residue. Caspase- 3 is the major active caspase in apoptotic cells, and its activation is a pivotal event in the execution of apoptosis $(39,40)$. In our present study, the activation of caspase- 3 was detected when the HaCaT keratinocytes were exposed to the Radix Rubiae extract, indicating unequivocally the occurrence of cellular apoptosis.

Collectively, our experimental results confirm that Radix Rubiae is capable of inducing programmed cell death in cultured HaCaT keratinocytes. The apoptotic actions observed in the present study provide an explanation for the underlying mechanism of the potent anti-proliferative property exhibited by Radix Rubiae on HaCaT cells. The successful identification of Radix Rubiae as a potent anti-proliferative and apoptogenic agent renders it a promising candidate and lays the groundwork for its further development into a herbbased topical therapeutic agent for psoriasis. Further experiments to evaluate the anti-psoriatic potential of Radix Rubiae as a topical agent on psoriasis animal models in vivo are now being conducted in our laboratory.

\section{Acknowledgements}

This study was supported by the Direct Grant, The Chinese University of Hong Kong (project a/c no. 2030317) and the Guangdong-Hong Kong Technology Cooperation Funding Scheme (ref. GHP/021/06).

\section{References}

1. Lebwohl M: Psoriasis. Lancet 361: 1197-1204, 2003.

2. Nickoloff BJ and Nestle FO: Recent insights into the immunopathogenesis of psoriasis provide new therapeutic opportunities. J Clin Invest 113: 1664-1675, 2004.

3. Camisa C: Handbook of Psoriasis. Blackwell Science, Malden, p137, 1998.

4. Schwartz PM, Barnett SK, Atillasoy ES and Milstone LM: Methotrexate induces differentiation of human keratinocytes. Proc Natl Acad Sci USA 89: 594-598, 1992.

5. Pol A, Bergers $M$ and Schalkwijk J: Comparison of antiproliferative effects of experimental and established antipsoriatic drugs on human keratinocytes, using a simple 96-wellplate assay. In Vitro Cell Dev Biol Anim 39: 36-42, 2003.

6. Takahashi H, Ibe M, Kinouchi M, Ishida-Yamamoto A, Hashimoto $Y$ and Iizuka H: Similarly potent action of 1,25dihydroxyvitamin D3 and its analogues, tacalcitol, calcipotriol, and maxacalcitol on normal human keratinocyte proliferation and differentiation. J Dermatol Sci 31: 21-28, 2003.

7. Bayliffe AI, Brigandi RA, Wilkins HJ and Levick MP: Emerging therapeutic targets in psoriasis. Curr Opin Pharmacol 4: 306-310, 2004.

8. Takahashi $\mathrm{H}$ and Iizuka $\mathrm{H}$ : Treatment of the keratinizing skin disorder, psoriasis, by topical vitamin D3. Clin Calcium 10: 129-132, 2004.

9. Wrone-Smith T, Mitra RS, Thompson CB, Jasty R, Castle VP and Nickoloff BJ: Keratinocytes derived from psoriatic plaques are resistant to apoptosis compared with normal skin. Am J Pathol 151: 1321-1329, 1997.

10. Laporte M, Galand P, Fokand D, de Graef C and Heenen M: Apoptosis in established and healing psoriasis. Dermatology 200: 314-316, 2000.

11. Bianchi L, Farrace MG, Nini G and Piacentini M: Abnormal Bcl-2 and 'tissue' transglutaminase expression in psoriatic skin. J Invest Dermatol 103: 829-833, 1994.

12. Reed JC: Bcl-2 family proteins. Oncogene 17: 3225-3236, 1998.

13. Kawashima K, Doi H, Ito Y, Shibata MA, Yoshinaka R and Otsuki Y: Evaluation of cell death and proliferation in psoriatic epidermis. J Dermatol Sci 35: 207-214, 2004.

14. Tse WP, Che CT, Liu K and Lin ZX: Evaluation of the antiproliferative properties of selected psoriasis-treating Chinese medicines on cultured HaCaT cells. J Ethnopharmacol 108: 133-141, 2006.

15. Chen R and Wang ZS: The isolation and elucidation of mollugin from Radix Rubiae. Cir Chin Materia Medica 13: 39, 1988.

16. Boukamp P, Petrussevska RT, Breitkreutz D, Hornung J, Markham A and Fusenig NE: Normal keratinization in a spontaneously immortalized aneuploid human keratinocyte cell line. J Cell Biol 106: 761-771, 1988.

17. Garach-Jehoshua O, Ravid A, Liberman UA and Koren R: 1,25Dihydroxyvitamin D3 increases the growth-promoting activity of autocrine epidermal growth factor receptor ligands in keratinocytes. Endocrinology 140: 713-721, 1999.

18. Farkas A, Kemeny L, Szony BJ, Bata-Csorgo Z, Pivarcsi A, Kiss M, Szell M, Koreck A and Dobozy A: Dithranol upregulates IL-10 receptors on the cultured human keratinocyte cell line HaCaT. Inflamm Res 50: 44-49, 2001.

19. Thielitz A, Bukowska A, Wolke C, Vetter R, Lendeckel U, Wrenger S, Hashimoto Y, Ansorge S, Gollnick H and Reinhold D: Identification of extra- and intracellular alanyl aminopeptidases as new targets to modulate keratinocyte growth and differentiation. Biochem Biophys Res Commun 321: 795-801, 2004. 
20. Nicoletti I, Migliorati G, Pagliacci MC, Grignani E and Riccardi C: A rapid and simple method for measuring thymocyte apoptosis by propidium iodide staining and flow cytometry. J Immunol Methods 139: 271-279, 1991.

21. Tounekti O, Belehradek J Jr and Mir LM: Relationships between DNA fragmentation, chromatin condensation, and changes in flow cytometry profiles detected during apoptosis. Exp Cell Res 217: 506-516, 1995.

22. Abrams JM, White K, Fessler LI and Steller H: Programmed cell death during Drosophila embryogenesis. Development 117: 29-43, 1993.

23. Gavrieli Y, Sherman Y and Ben-Sasson SA: Identification of programmed cell death in situ via specific labeling of nuclear DNA fragmentation. J Cell Biol 119: 493-501, 1992.

24. Portera-Cailliau C, Sung CH, Nathans J and Adler R: Apoptotic photoreceptor cell death in mouse models of retinitis pigmentosa. Proc Natl Acad Sci USA 91: 974-978, 1994.

25. Sgonc R, Boeck G, Dietrich H, Gruber J, Recheis H and Wick G: Simultaneous determination of cell surface antigens and apoptosis. Trends Genet 10: 41-42, 1994.

26. Ernst JD, Yang L, Rosales JL and Broaddust VC: Preparation and characterization of an endogenously fluorescent annexin for detection of apoptotic cells. Anal Biochem 260: 18-23, 1998.

27. Fadok VA, Voelker DR, Campbell PA, Cohen JJ, Bratton DL and Henson PM: Exposure of phosphatidylserine on the surface of apoptotic lymphocytes triggers specific recognition and removal by macrophages. J Immunol 148: 2207-2216, 1992.

28. Martin SJ, Reutelingsperger CP, McGahon AJ, Rader JA, van Schie RC, LaFace DM and Green DR: Early redistribution of plasma membrane phosphatidylserine is a general feature of apoptosis regardless of the initiating stimulus: inhibition by overexpression of Bcl-2 and Abl. J Exp Med 182: 1545-1556, 1995.

29. Vermes I, Haanen C, Steffens-Nakken H and Reutelingsperger C: A novel assay for apoptosis. Flow cytometric detection of phosphatidylserine expression on early apoptotic cells using fluorescein labelled Annexin V. J Immunol Methods 184: 39-51, 1995.
30. Boehm I: Apoptosis in physiological and pathological skin: Implications for therapy. Curr Mol Med 6: 375-394, 2006.

31. Krueger JG, Wolfe JT, Nabeya RT, Vallat VP, Gilleaudeau P, Heftler NS, Austin LM and Gottlieb AB: Successful ultraviolet $\mathrm{B}$ treatment of psoriasis is accompanied by a reversal of keratinocyte pathology and by selective depletion of intraepidermal T cells. J Exp Med 182: 2057-2068, 1995.

32. Benassi L, Ottani D, Fantini F, Marconi A, Chiodino C, Giannetti A and Pincelli C: 1,25-dihydroxyvitamin D3, transforming growth factor beta1, calcium, and ultraviolet B radiation induce apoptosis in cultured human keratinocytes. J Invest Dermatol 109: 276-282, 1997

33. McGill A, Frank A, Emmett N, Turnbull D, Birch-Machin MA and Reynolds NJ: The anti-psoriatic drug anthralin accumulates in keratinocyte mitochondria, dissipates mitochondrial membrane potential, and induces apoptosis through a pathway dependent on respiratory competent mitochondria. FASEB J 19: 1012-1014, 2005.

34. Lei ZQ, Chen SY and Gao XM (eds): Chinese Materia Medica. Shanghai Science and Technology Press, Shanghai, p189, 1995.

35. Fang XY, Sun YH, Yang LS and Miao MS: Progress in the research on Rubiae Cordifolia. Arch Henan Chin Med 17: 78-80, 2002.

36. Compton MM: A biochemical hallmark of apoptosis: internucleosomal degradation of the genome. Cancer Metastasis Rev 11: 105-119, 1992.

37. Wyllie AH: Glucocorticoid-induced thymocyte apoptosis is associated with endogenous endonuclease activation. Nature 284: 555-556, 1980

38. Barry MA and Eastman A: Identification of deoxyribonuclease II as an endonuclease involved in apoptosis. Arch Biochem Biophys 300: 440-450, 1993.

39. Hoshi T, Sasano H, Kato K, Yabuki N, Ohara S, Konno R, Asaki S, Toyota $\mathrm{T}$, Tateno $\mathrm{H}$ and Nagura $\mathrm{H}$ : Immunohistochemistry of Caspase $3 /$ CPP32 in human stomach and its correlation with cell proliferation and apoptosis. Anticancer Res 18: 4347-4353, 1998 .

40. Kirsch DG, Doseff A, Chau BN, Lim DS, De Souza-Pinto NC, Hansford R, Kastan MB, Lazebnik YA and Hardwick JM: Caspase-3-dependent cleavage of Bcl-2 promotes release of cytochrome. J Biol Chem 274: 21155-21161, 1999. 